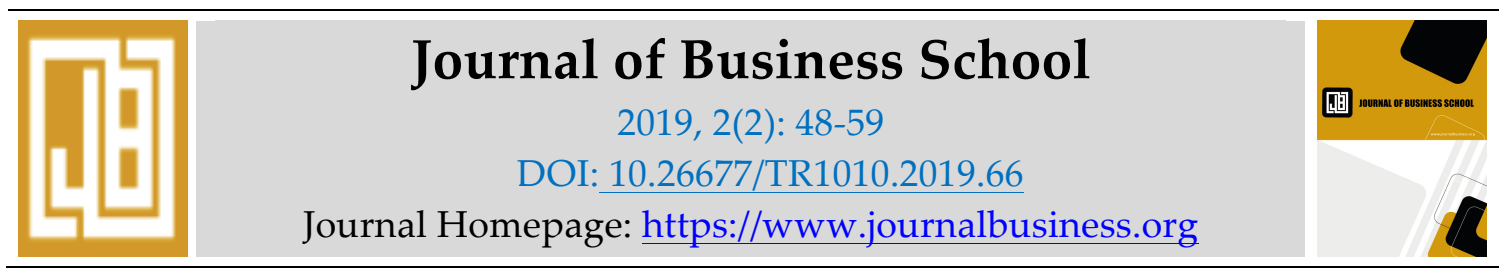

\title{
Microfinance Development in Nigeria
}

\author{
Aminu Bello \\ Department of Economics, Faculty of Arts and Social Sciences, Gombe State University. \\ Nigeria. aminubell1@gmail.com
}

\begin{abstract}
Attainment of economic growth and development is one of the basic macroeconomic objectives that every country is pursuing to achieve. However, the problem of poverty and its consequences is making it difficult for many countries especially those in Sub-Saharan Africa to realize their growth potentials. Example of such countries is Nigeria with population of about one-hundred and eighty million out of which more than $70 \%$ of the population are struggling with the problem of poverty i.e. they could not meet their basic necessities of life including food, clothing, housing/ shelter, safe drinking water, qualitative education, good health care system e.t.c. As a result of this, different strategies and methods have been put in place by government in the country with the aim of fighting poverty in the country generally. Establishment of institutions like National Directorate of Employment (NDE), Directorate for Food, Road, and Rural Infrastructure (DFRRI), Operation Back to Farm, Green Revolution, National poverty Eradication Programme (NAPEP), Microfinance Scheme, Subsidy Reinvestment Programme (SURE-P), e.t.c. are all examples of government programmes that are designed purposely to address the problem of poverty directly or indirectly in Nigeria. Government's effort in fighting poverty in Nigeria is also supported by the international development partners through UNDP, IFAD, FAO and NEPAD whose main priority is to assist the developing countries in their pursuit of eradicating poverty particularly in the rural communities.
\end{abstract}

Keywords: Microfinance, Development ,Nigeria

\section{INTRODUCTION}

Microfinance is generally understood as the provision of basic financial services including savings, credit, money-transfer and even insurance, to the poor - or in a broader sense, those who are unable to access such services due to exclusion by the mainstream retail banking sector (Robinson, 2011). Among factors that distinguish microfinance from other forms of formal financial institutions are; smallness of the loans, advances and savings collected, near absence of asset-based collateral and simplicity of operations. Therefore, microfinance can be described as a poverty alleviation strategy which operates by providing credit and other financial services to economically active and low income individuals and their businesses. Microfinance has found widespread acceptance from the early days of the 1970's. Many countries have already enacted legislations to formalize the sector through regulation, allowing some banking activities, such as taking deposits and extending deposits protection, in addition to lending. In other countries, 
microfinance institutions (MIFs) are restricted to lending activities only or are unregulated. A regulated sector with customer protection is an important element in building capacity in this area. Micro credit loans involve group responsibilities. The process starts with membership in a group. For example, a group of five unrelated individuals. An initial period of regular (weekly) savings is required and after a certain number of weeks, members of the group become eligible to take out loans. The loan is the multiple of the amount saved (from two to as high as five times); there is collective responsibility to ensure payment of the loans. When member of a given group defaults to pay back the loan he obtains from the bank, the repercussion of that act would be felt by other members of the group.

Modern micro credit is generally considered to have originated with the Grameen Bank founded in Bangladesh in 1983. Many traditional banks subsequently introduced micro credit scheme into their operations, despite initial misgivings. The United Nations declared 2005 as the International Year of Micro credit. These days, micro credit is widely used in developing countries and is presented as having enormous potentials as a tool for poverty alleviation. In Africa and other developing regions, microfinance institutions (MFIs) are regarded as the main source of funding to micro enterprises (Anyawu, 2004).

The practice of microfinance is not new in Nigeria because Nigerians have always tried to provide themselves with needed finance through informal microfinance approaches like SelfHelp Groups (SHGs), Rotating Savings and Credit Associations (ROSCAs), Accumulating Credit and Savings Associations (ASCAs) and direct borrowings from friends and relations (Nwankwo, 2008). These approaches may have sufficed in the traditional society but the growth in the sophistication of the economy and the increasing incidence of poverty among citizens has revealed the shortcomings of this approach. In 2005, the Central Bank of Nigeria (CBN) alluded to this when it pointed out that the informal financial institutions that attempt to provide microfinance services generally have limited outreach due primarily to paucity of loanable funds (CBN, 2005). It was in a bid to resolve this defficiency of the informal microfinance sector that the CBN in 2005 further introduced a microfinance policy, a prelude to the licensing of microfinance banks in Nigeria. According to this policy document, its aim is to provide a microfinance framework that would enhance the provision of diversified microfinance services on a long-term sustainable basis for the poor and low income groups, create a platform for the establishment of microfinance banks and improve CBN's regulatory / supervisory performance in ensuring monetary stability and liquidity management. Therefore, microfinance banks in Nigeria are established because of the failure of the existing microfinance institutions to adequately address the financing needs of the poor and low income groups (Acha, 2008). The CBN further justified its licensing of microfinance banks with lack of institutional capacity and weak capital base of the existing community banks at that time, existence of huge un-served market and need for increased savings opportunity (CBN, 2005). Taking the issue of lack of capacity by existing financial institutions further, the CBN pointed out that only $35 \%$ of Nigerians had access to financial services and that most of those without access to financial services dwell in the rural areas. In the same vein, (Nwankwo, 2008) noted that over $95 \%$ of the businesses in Nigeria are small and that conventional banks choose not to finance such businesses. This is attributed to the high risks inherent in them and their inability to provide asset-based collateral. Microfinance banks are mostly established to meet the shortfall in financing small businesses own by the entrepreneurial poor.In line with this, microfinance programme was launched in Nigeria to empower micro, small and medium scale enterprises through loans and savings products, thus helping to lift them out of poverty while increasing their contributions to GDP. Other objectives of the scheme include: 
(i) Complementing to poverty reduction through small and micro credit interventions by government at all levels as well as supplying cheap sources of finance to small and medium entrepreneurs.

(ii) Ensuring wider and equitable distribution of credit around the country to deserving entrepreneurs in their respective states.

(iii) Motivating the states and local governments to comply with the requirement of the microfinance and regulatory framework for Nigeria so that they should devote at least one percent of their annual budgets to the development microfinance in their areas.

(iv) Strengthening the institutional, organizational and technical capacity of the agencies that will administer the credit including the microfinance banks and the beneficiaries (CBN, 2005).

As earlier stated, microfinance banks were founded because of the perceived deficiencies in the existing financing schemes in Nigeria. They were licensed to begin operations in 2007 together with the existing community banks then as well as the Non-Governmental (NGO) microfinance institutions that met the conditions spelt out by CBN for licensing were also allowed to transmute into microfinance banks. To qualify for a microfinance license, existing community banks were required to increase their paid-up capital from $\$ 5 \mathrm{~m}$ to $\$ 20 \mathrm{~m}$. Unlike the community banking policy framework which compulsorily confined all community banks to unit banking, the microfinance banking guideline permitted the branching of microfinance banks within a state. For the microfinance banks intending to open branches within a state, their paid-up capital was put at $\$ 1$ billion. Another point of divergence between the community banks and their microfinance successors is in terms of the regulating guidelines allowing to own them. In addition to individuals, group of individuals, community development associations, private corporate entities which could own community banks, foreign investors could also own microfinance banks. These changes in the policy framework establishing microfinance were due to the perceived failure of the existing microfinance framework. Adeyemi, (2008), captured this by stating that "despite all the effort made by the government in providing funds meant for growth of small businesses in the Nigeria, supply of credit to owners of small business is still inadequate". 'despite decades of public provision and direction of provision of micro credit, policy orientation and entry of new players, the supply of micro credit is still inadequate'. He identified some of the changes which microfinance institutions face which has impinged on their ability to perform to include: undercapitalization, inefficient management and regulatory \& supervisory loopholes. To these, (Mohammed etal, 2009) added usurious interest rates and poor outreach. Further buttressing the changes facing microfinance banks, (Nwanyanwu, 2011) identified diversion of funds, inadequate finance and frequent changes in government policies, heavy transaction costs, huge loan losses, low capacity and low technical skill in the industry as impediments to the growth of this sector. These challenges many of which contributed to the failure of previous microfinance schemes are still bedeviling the microfinance banking scheme in Nigeria.

As at now, there more than 870 institutions have been duly registered and approved to operate as microfinance banks in Nigeria. In addition to this, some of the deposit money banks have been setting up subsidiaries, while others have been partnering with microfinance banks in the programme. State governments and Non-Governmental organizations are equally supporting the scheme through setting up microfinance gencies and capital lending respectively.

\section{STATEMENT OF THE PROBLEM}

Poverty eradication is one of the major goals which many countries of the world especially the developing ones have been trying to achieve over the years in an attempt to improve the 
standard of living of their people. The magnitude and expansion of poverty as well as the great threat it poses to social, political and economic stability makes it one of the biggest challenge facing virtually all the less developed countries these days.

Nigeria is blessed with enormous human and material resources. However, majority of its citizens are living with poverty. Incidence of poverty is high in the country. It is said that the country has one of the highest poverty level in the world because about $70 \%$ of its 167 million people are living on less than US $\$ 1$ a day (World Bank, 2012). Faced with this scenario, governments at various levels (Federal, State and Local) have been making efforts to see how these problems can be addressed. In doing so, different programmes and policies have been introduced with the aim of fighting poverty. However, despite all the effort that has been made, incidence of poverty is still high.

In 2005, microfinance began to be embraced as a tool of poverty eradication in Nigeria. The goal of microfinance is to improve the welfare of the poor directly without any hindrance through economic empowerment, employment and income generation.

\section{MICROFINANCE BANKS AND POVERTY ALLEVIATION IN NIGERIA}

Microfinance is a term used to describe different methods that give poor people access to financial services. Irobi (2008), defined it as the provision of financial services such as credits (loans), savings, micro-leasing, micro-insurance and payment transfers to economically active poor and low income households to enable them engage in income generating activities or expand/grow their small businesses. Therefore it can be viewed as a financial intervention that focuses on the low income group of a given society. The intervention may primarily involve giving credit services and may also include savings, insurance on credits and savings. Further more, Robinson (2001), defined microfinance as the supply of loans, savings and other financial services to the poor. Microfinance is defined as "the provision of financial services i.e savings and credit to resource poor people" (Adedoja, 1999). According to him, provision of these services to very poor household creates opportunity for the poor to create, own and accumulate assets and to smoothen their consumption. Microfinance evolved as an economic development approach intended to benefit the low-income part of a given society, both men and women (Irobi, 2008). According to world Bank (2007), the term "microfinance" refers to the provision of financial services (including savings and credit) to the poor. The objective of microfinance according to Otero (1999) is not providing capital to the poor to combat poverty, it seeks to create an institution that delivers financial services to the poor who are ignored by the formal banking sector. Microfinance deals with small scale financial services provided to people who farm, fish or herd; who operate small enterprises or micro enterprises where goods are produced, recycled, repaired or sold; who provide services, who work for wages or commissions; who gain income from renting out small amount of land, vehicles, draft animals or machinery and tools, and to other individuals and groups at the local levels of developing countries, both rural and urban (Robinson, 2001). Microfinance banks are therefore institutions that are established to provide financial services to the poor. The institutions could be nongovernmental organizations, saving and loan cooperatives, loan unions, government banks, banks and non-banks financial institutions (Ledgerwood, 1997). The vision of most microfinance schemes is to transform the economic and social structures in a society by offering financial services to households with low incomes (Morduch, 1999.) A growing body of evidence links the provision of credit to the poor and a reduction in poverty through the creation of employment, the earning of more regular income, and consumption smoothening. Availability of credit has the potential of enabling poor individuals to become economically active, thus earning more regular income, acquiring assets, and becoming collectively less vulnerable to risk. 
The objective of the first United Nation's Decade for the Eradication of Poverty (1997-2006), as proclaimed by the General Assembly in its resolution 50/107 or 20 December, 1995, is to achieve the goal of eradicating absolute poverty through national action and international cooperation. Progress on the anti-poverty front was reported to the General Assembly in the report to the Secretary General entitled "Observance of the International Year for the Eradication of Poverty (1996) and Recommendations for the Rest of the Decade" (A/52/573).

The General Assembly in its resolution 52/194 of 18 December 1997, noted that, in many countries microcredit programmes have proved to be an effective tool in freeing people from poverty and have helped to increase their participation in the economic and political processes of their societies. Among other provisions, the Assembly called upon the relevant organs, organizations and bodies of the United Nation's system in particular, its funds and programmes and the regional commissions, as well as the relevant international and regional agencies involved in the eradication of poverty to explore including the microcredit approach in their programmes as a tool for the eradication of poverty. The Assembly requested the Secretary - General in collaboration with relevant organizations of the United Nations system including funds and programmes and the World Bank to submit it at its Fifty-Third session in the eradication of poverty. The World Summit for Social Development held in Copenhagen in March, 1995, also underlined the importance of improving access to credit for small rural or urban producers, landless farmers, and other people with low or no income, with special attention to the needs of women, disadvantaged and vulnerable groups. Government were called upon subsequently to review national legal, regulatory and institutional frameworks that restricts the access of people living with poverty especially women to credit on reasonable terms, to promote realistic targets for access to affordable credit, providing incentives for improving access to and strengthening the capacity of organized credit and related services to people living in poverty and vulnerable groups; and to expand the financial networks, building on the existing networks, promoting attractive opportunities for savings and ensuring equitable access to credit at the local levels. It is now broadly accepted that robust economic growth that is labour intensive and equitable, combined with larger outlays of social expenditures, especially directed towards the poor, are the winning combination in the fight against poverty. Also there has been a growth in the recognition of the importance of empowering all people by increasing their access to all the factors of production, including credit. In addition, the value of the role of the non-governmental organizations in development is receiving more attention. It is that context that micro credit has recently assumed a certain degree of prominence. It is based on the recognition that the latent capacity of the poor for entrepreneurship would be encouraged with the availability of small scale loans and would introduce them to the small enterprise sector. This could allow them to be more self-reliant, create employment opportunities, and not least engage women in economically productive activities.

Over the past decades, microfinance institutions have adopted innovative ways of providing credit and saving services to the entrepreneurial poor. Two approaches have been advocated on the role of credit in poverty reduction. While supporters of the income generation approach maintain that credit should be provided mainly to the entrepreneurial poor to enable them finance specific private income generating activities to increase their revenues, proponents of the new maximalist approach argue that credit programmes would still be helping the poor fight poverty by given credit to any poor person who is able to repay a loan without dictating to that person how and on what the loan should be used. Some studies have pointed out that the problem of the non-productive use of credit, as advocated by the minimalist approach, lies in the fact that by consuming rather than investing their loans, the actions of such borrowers, if 
imitated by other poor people, could produce a negative impact on the future growth of micro credit programmes in the economy.

The impact of micro credit with regard to poverty alleviation has been a subject of controversy in many countries today. While its proponents state that is reduces poverty through higher employment and higher income, which is expected to lead to improve education of the borrower's children. Some argue that micro credit empowers women. In US and Canada, it is argued that micro credit helps its recipients to graduate from welfare programmes. However, critics say that micro credit has not increased incomes, but has driven poor households into a debt - trap, in some cases even leading to suicide. They added that the money from loans is often used for durable consumer goods or consumption instead of being used for productive investments, that it fails to empower women, and that it has not improved health or education of the poor in many countries. Available evidence indicates that compared to the number of micro loans advanced, micro credit has facilitated the creation and the growth of a tiny number of businesses. Going further, the extremely high rate of failure associated with most informal micro enterprises often leaves the average individual micro-entrepreneur worse off in the long run, when his assets, land and housing have to be sold off to repay an outstanding micro loan. In addition, new poverty-push micro-entrepreneurs also take business away from already struggling micro enterprises which reduces the turnover of the existing businesses and so also their net income. Taking both downside effects into account, this generally means that there is no net positive impact arising from the application of micro credit. This is especially the case in the poorest locations where there has been very little demand from local people for the micro enterprises that micro credit helps to create. Therefore, while micro credit often guarantee self employment opportunities, it does not necessarily increase income after interest payments. In fact, the opposite tends to occur; the increasing poverty-push over supply of simple informal micro enterprises in the poorest communities is increasingly associated with filling average incomes. Because of this, in 2009 for instance, International Labour Organization (ILO) had to argue against further stimulation of the informal micro enterprises sector as a response to the rising unemployment and poverty associated with the global financial crisis, since as was the case of previous crises, this could generate substantial downward pressure on informal wages which before the crisis were already declining in a growing number of developing countries. The deployment of micro credit programmes has simply driven large number of borrowers into debt-trap such as in Bolivia, Antheara Pradesh states in India, Bosunia, Morocco, Nicaragua and, perhaps the most egregious case of all, in Peru where the population of 30 million has to absorb more than \$US 10 billion of micro loans.

There is growing evidence that the expanding informal sector actually undermines the growth and development of the much more developmentally important formal sector comprising of small, medium and large business. Vargas has identified this "Crowding out" phenomenon in micro credit "Saturated" Bolivia. In short, micro credit has achieved much less than what its proponents said would achieve, if indeed it has not wasted scarce financial resources that could have been better invested elsewhere, though some still claim that its negative impacts have not been as drastic as some critics have argued. Micro credit is just one factor among factors that influence the success of a small businesses, whose success is influenced to a much larger extent by local demand and how much an economy or particular market grows.

\section{EMPIRICAL LITERATURE REVIEW}

Following the perceived success of the Grameen Bank and other Microfinance Institutions (MFIs) in recent years, the use of MFIs as a policy device for poverty alleviation has been increasing in many countries around the world. While Some empirical evidence from the researches conducted on the impact of microfinance schemes on poverty alleviation have 
shown positive results, other evidence shows negligible or even negative impact and suggest that most MFIs are profit oriented and they always aim for financial sustainability. Such programmes do not benefit the poorest of the poor (Amin, Rai and Topa, 2003.) Among the schemes most cited in this respect are the Grameen Bank of Bangladesh, Bank Rukyat of Indonesia, Bancosol of Bolivia, the Bank Kreda Desa of Indonesia, etc.

Maes and Basu (2005), found that members of the 'Tricle Up Seed Capital', a microfiance scheme in rural India that targets the vulnerable (especially rural landless, female-headed households, people with disabilities and economically disadvantaged minorities) who received loans and invested the funds on different assets purposely to expand their income generation activities. This enabled them to earn a more regular income during the farming season than hitherto. Although most of the employment generated was seasonal, clients worked until the end of the season. Also, the number of income generation ventures for TUP clients increased by $41 \%$. This helped not only to improve household's income but also reduce risk and vulnerability. They also found that before the TUP project, average annual income for the greater number of clients were in the lowest two income categories (below 5000Rs and between 5000Rs to 1000Rs). After they joined the scheme, it was discovered that all members had average annual income greater than 5000Rs and at least every member had moved one levl up the income ladder.

Hartarska and Nadolnyak (2008), used Living Standard Measurement Survey Data for Bosnia and Herzegovina and the Microfinance Industry Annual Report in 2001 to evaluate the impact of MFIs. They found that new clients of microfinance schemes enjoyed increase in household's income, employment and wages. They claimed that other studies show higher income for members of microfinance programmes compare to non-clients with comparable characteristics from the same sample.

Consumption smoothening is another area jn which poor people who borrowed from MFIs benefited, thus reducing their vulnerability to fluctuating incomes (Morduch, 1999). In one of the most cited studies of group-based programmes, Pitt and Khandker (1998), made a detailed study of the three leading MFIs in Bangladesh and found that women borrowers had their household consumption increased by 18 taka with every additional 100 taka borrowed. With the improvement in income earnings, $5 \%$ of borrowers in the same study move out of poverty annually after participating in microfinance schemes. The benefits were sustained over time, with spill over effects and increased economic activities generally. These results were corroborated by Khandker (2005), who employed panel data to improve on Pitt and Khandker's 1998-model.

According to the systematic review of the impact of micro credit conducted in 2011 by group of researchers on behalf of the United Kingdom Department for International Development (UKDFID)," there is no good evidence for the beneficent impact of microfinance on the wellbeing of poor people and that the greatest impact are reported by studies with the weakest designs. The attempt to objectively evaluate the impact of micro credit on a global or local scale is marred by numerous methodological challenges and the deliberate deployment of faulty and biased methodologies that are designed to identify only positive impact and to ignore negative impact. Thus, there are only few rigorous evaluations of micro credit and much of the literature on the impact of micro credit is based in anecdotal reports or case studies that are not representative. Even among the rigorous evaluations many suffer from weak methodologies and inadequate data". The first randomized evaluation of the impact of introducing micro credit in a new market has been undertaken by Abhijit Benerjee of the Massechusetts Institute of Technology (M. I. T) Poverty Action Lab for Slums in Hyderabad, India, in 2008. The study compared two groups of randomly selected slums. In the treatment group, banks opened 
branches that provide micro credits, while in the control group, this was not the case. The study showed that 15-18 months after lending began, there was no effect on average monthly expenditure per capita, but expenditure on durable goods increased. Consumption thus shifted from consumable to durable goods. Also, the number of new businesses increased by one-third but they were not very profitable. According to Tazul (2007), Grameen Bank does not reach the poorest, since the clients of the bank tend to be clustered around the poverty line of predominantly moderately poor or vulnerable non-poor of the poor who join Grameen Banks micro credit programmes, a high percentage often drop out after only a few loan cycles while many others eventually begins to exceed their repayment capacity. Nevertheless, he concludes that micro credit in Bangladash had a "Positive impact on enterprise and household income and assets accumulation". Micro credit in the US have allowed small business owners to make their businesses become their primary source of income with $67 \%$ of the borrowers showing a significant increase in their income as a result of their participation in certain micro-loan programmes. Bartmann (2010) the author of Why Doesn't Microfinance Work? argued that micro credit offers only an "illusion of poverty reduction". "As in any lottery or game of chance, a few in poverty do manage to establish micro enterprises that produce a decent living." Bateman concludes that "The international development community is now faced with the reality that, overall microfinance has been a development policy blunder of quite historic proportions". According to him, one third of micro credits are taken in order to pay for food or health care, especially during the times of the year called Monga when food and work opportunities are scarcest. Children drop out of school to earn money and families cut down their food expense in order to repay loans. When natural disasters strikes, weekly installments to repay loans continue although the ability of borrowers to earn income has been destroyed by the disasters. Tazul Islam (2007) also asserts a positive influence of micro credit on the level of education, health and nutrition. According to him, in US, micro credit has created jobs directly and indirectly, as $60 \%$ of borrowers were able to hire others. Business owners in the US were able to improve their housing situation after their income have improved due to business expansion. Facilitated by micro loans, 70\% indicated that their housing condition has improved. Ultimately, many of the small business owners that use social funding are able to graduate from government funding. According to some reports in the US, every domestic micro credit loan creates 2.4 jobs. These enterprises provide wages that are on average $25 \%$ higher than minimum wage. The 2005 review published by the Grameen Foundation summarized scores of studies, concluding that "Society - wide benefits that go beyond clients' families are apparently significant". Based on the evidence of two rigorous evaluations in India and Manila, Nicholas Kristof concludes that "there is no evidence that micro credit has any effect on health or education". Recent studies on the impact of microfinance on poverty alleviation have shown positive result as (Wright, 2000; Adamu, 2007 and Irobi 2008) all subscribed to the believe that microfinance is an effective and powerful tool for poverty reduction. Rai and Topai (2003) focus on the impact of microfinance to reach the poor have affirmed that microfinance has served people who are living under poverty line. Also, Hossain (1998), in his study on "Credit for the Alleviation Rural Poverty in Bangladesh" found that Grameen members who are poor and landless have average household of 43 per cent higher than marginal land owners. The result of empirical evidence indicates that the poorest can benefit from microfinance from both an economic and social well-being point of view, and that this can be done without jeopardizing the financial sustainability of the microfinancial institutions, (Robinson, 2001; Dahiru and Zubair, 2008). Khandker (1998) in several related studies using statistical method on assessment of the impact of microfinance among the people living with poverty found that every taka lend to a woman add 0.18 takas to annual household expenditure. Similarly, in an updated study using panel data in Bangladesh, Khandker (2005) found that each additional 100 taka of credit 
to women increase total annual household expenditure by more than 20 taka. These studies showed overwhelming benefit of increase in income and reduction of vulnerability. On the other hand, some studies have challenged the positive effects of microfinance on poverty alleviation. For instance, Hulme and Mosley (1996), while acknowledging the role that microfinance can play in helping to reduce poverty, concluded from their research on microfinance that " most contemporary schemes are less effective than they might be" they stated that microfinance is not a panacea for poverty alleviation and that in some cases the poorest people have been made worse-off by microfinance.

Nudamatiya, Giroh and Shehu (2009), studied the Impact of Microfinance on Poverty Reduction in Adamawa State. The study used a simple random selection of 88 beneficiaries of four microfinance institutions through a questionnaire survey. Data collected were analyzed using descriptive and inferential statistics. Their study revealed that microfinance has positive impact on the beneficiaries of the microfinance credit. Noah and Muftau (2009), study on the impact of micro credit on poverty reduction in the informal sector of Offa, was carried out by the use of a collection of household data and regression analysis. The result shows that informal financial institutions helped to smoothened temporary shocks in the household consumption and made them have enough funds to restock supplies in their businesses which in the long run help to improve their living standard and those of their families. Olaitan's study (2005), on the impact of microfinance on poverty reduction revealed that access to microfinance is very important because it enables the poor to create, own and accumulate assets and smoothened their consumption. Anan (2003), observe that "sustainable access to microfinance helps alleviate poverty by generating income, enabling families to obtain health care and empowering people to make the choice that best serve their needs.

Lambert and Manlagnit (2003) conducted a study in Philippines to evaluate the incidence of poverty amongst microfinance beneficiaries according to the gender of households headed. Their methodology of study involves descriptive analysis based on the comparison of the household characteristics to specify the differential effects of access to the community-oriented financial institutions (COFI) system through the distinction of two groups: male and female heads of household. More specifically, as far as beneficiaries are concerned, the study found that households headed by women seem to be poorer than households headed by men. Concretely, the poverty incidence for households headed by women is 16.7 percent compared to only 8.8 percent among male headed households.

Koloma (2008) used cross-section data to determine the effects of microfinance on poverty alleviation in Mali by adopting the Method of Propensity Score. The study indicates that micro credit produces a positive and important impact on poverty alleviation for all its beneficiaries but its effects on men and women beneficiaries are quite different both in terms of significance and in terms of size effect. In sum, the micro credit effects on poverty among women beneficiaries are relatively higher than those of male beneficiaries.

\section{CONCLUSION AND RECOMMENDATIONS}

Poverty is generally seen as a constraint that leads to poor growth and development of an economy. Therefore, promotion of any economy must start by exploring the potentials of increasing employment opportunities, sustain increase in capital formation, provision of overhead, reduce income disparities, streaming premature rural-urban drift, development of agriculture and small and medium scale enterprises and ultimately reducing poverty from the grassroots level. According to United Nation's programme tagged Millennium Development Goals (MDGs) proposed as one of its objectives "To eradicate poverty by $50 \%$ by the year 2015 ". In line with the programme, some countries are making tremendous progress in reducing the 
number of people who suffer from poverty or reducing the rate of poverty levels among people. This study aimed to examine the impact of microfinance banks on poverty alleviation.

On the basis of the general findings of the study, the following recommendations are proposed:

(i) Since continuity is important in all aspects of development, microfinance as a strategy for the eradication of poverty should be maintained to ensure that its benefits reach every poor individual in Nigeria.

(ii) More opportunities should be created for poor individuals towards accessing microfinance services in the country so that those who deserve to benefit from the scheme are given chance to have direct access to the services without any hindrance.

(iii) More microfinance institutions should be provided in villages and other remote areas so as to serve the rural poor since most of the institutions are now operating within the urban centres.

(iv) Public awareness campaign should be embarked upon to educate people more on the general procedures, aims and objectives of the microfinance scheme in the country.

(v) More support should be given to the scheme by government through provision of more funds for the programme.

(vi) Regular supervision and inspection should be maintained to avoid problem of mismanagement of the funds meant for the scheme.

(vii) New policy should be formulated to ensure that individuals with large household size receive special financial support from the government to improve their condition of survival.

\section{REFERENCES}

Aboyade, O., (1975) Need for Operational Specification of Poverty in Nigeria. Proceedings of 1975 Annual Conference of Nigeria Economic Society.

Acha, I. A., (2008) Borrowing Cycle: Alternative Micro Financing Model for Nigeria. African Journal of Entrepreneurship, 1(3), pp46.

Adekunle, A.A., (2009) Theoretical Perspectives on Poverty Reduction: Challenge for Policy in Nigeria. International Journal of Economics and Development Issues Vol. 8 No: 1 \& 2.

Adeyemi, K. S., (2008) Institutional Reforms for Efficient Microfinance Operation in Nigeria. CBN Bullion, 32(1), $26-34$.

Adeyomi, O.A., (1991) “Women in Development” NCEMA National Workshop Report, Ibadan.

Adetunbi, O., (1999) “ Micro Credit Scheme in Nigeria :s in Micro Credit Delivery in the Niger Delta" Paper presented at the SPDC

Ajekaiye, D.O. and Olumola, A.S., (2003) "Overview of Poverty and Poverty Reduction in Nigeria. A Multi-Dimensional Perspective"

Anele, K., (2000) Social Stratification and Inequality: An Introductory Text. Emhari Printing and Publishing Company, Porthacourt.

Arinze, A., (1995) “Poverty Reduction in Nigeria; Policy Option CBN Bullion, Vol. 19, No. 2

Attahiru M. J. and Haruna W., (2002) The Poverty Eradication Programme in Nigeria; Problems and Prospects. Centre for Democratic Research and Training, Mambayya House, Bayero University,Kano. 
Babashola P., (1997) Funding of Poverty Alleviation Programmes in Nigeria. Paper Delivered at the National Stakeholders Workshop on Poverty Abuja, 19 $-21^{\text {st }}$ September.

CBN, (2005) Microfinance Policy Regulatory and Supervisory Framework for Nigeria. Abuja: CBN.

CBN, (2006) CBN Annual Report.

Demery, S., (1996) Key Issues in the Design and Management of Targeted Poverty Alleviation Programmes. Paper Presented at the Workshop on Design and Management of Poverty Reduction Programmes, Economic Development Institute. Washington DC.

Desai, B., (1992) Education, Democracy and Poverty Reduction in Africa.Macmillan Publishers, pp, 262-276.

Ehigiamusue, G., (2000) Poverty and Microfinance in Nigeria.OBZED Publishers, Benin.

Enwere, D., (1996) Integrating Poverty Alleviation Strategies into Plan and Programme: Meaning and Dimensions of Poverty.

Gibbons, D. S. and Kasim S., (1991) Banking in the Rural Poor in Peninsular. Malaysia Centre for Policy Research, Malaysia.

Holcombe S. (1993) "Managing in Empower" The Grameen Bank's Experience of Poverty Alleviation. University Press, Dhakar.

Hulme, D. and Mosley, P., (1996) Finance Against Poverty. Routledge: London

Isma'il, O.F and Adegbemi, O., (2012) Microcredit as a Tool for Poverty Alleviation in Ogun State, Nigeria. Journal of Sustainable Development in Africa Volume 14 No. 8

Khandker S. R., (1998) "Micro Credit to Advance Women: Fighting Poverty with Micro Credit, Experience in Bangladesh" Grameen Dialogue pp 13

Koloma Y., (2008) Microfinance and Gender: Poverty Assessment of Beneficiaries in Mali.

Lamberte M. B., Manlagnit M. C. V. (2003) Poverty and Access toMicrofinance with Gender Dimension, Discussion Paper Series 2003- 2007. Philippine's Institute for Development Studies.

Milford, B., (2010) Why Doesn't Microfinance Work? The Destructive Rise of Local Neoliberalism.

Mohammed, A. D., and Hassan, Z., (2009) Microfinance in Nigeria and the Prospects of Introducing an Islamic Version in the Light of Selected Muslim Countries Experience. Review of Islamic Economics, 13(1) pp $115-174$.

Nwankwo, O., (2008) Microfinancing and Poverty Reduction in Nigeria: Challenges and Prospects. Journal of Business Administration and Management, 3(1), 41 - 46.

Nwanyanwu, O. J., (2011) Microfinance in Nigeria: Problems and Prospects. African Research Review, 5(2), 87 - 103.

Obadan M.I., (1997) Analytical Framework for Poverty Reduction, Issue of Economic Growth versus other Strategies. Proceedings of the Annual Conference of the Nigeria Economic Society (NES), Ibadan.

Obadan M.I., (2003) Poverty Reduction in Nigeria the Way Forward. Central Bank of Nigeria Economic and Financial Review Vol.39 No. 4 
Obi, F., (2006) Microfinance: The challenges Ahead. Independent Newspaper, 19th June 2006.

Ogwumike F., (2002) An Appraisal of Poverty Reduction Strategies in Nigeria. Central Bank of Nigeria Economic and Financial Review Volume 39.

Olu A., (2002) Overview of the Current Poverty Eradication Programme in Nigeria. Proceedings of the Round-Table Discussion on Poverty Eradication Programme in Nigeria Organized by the Centre for Democratic Research and Training (CDRT), Mambayya House, Bayero University, Kano.

Robinson, S. M., (2001) The Microfinance Revolution: Sustainable Finance for the Poor. World Bank's open Society Institute Washington D.C.

Rutherfold, S., (1999) The Poor and Their Money: An Essay About Financial Services for Poor. Institute of Development, Policy and Management, University of Manchester.

Stiglitz, P., (1999) Assessing the Impact of Micro-credit on Poverty and Vulnerability in Bangladesh. World Bank Policy Research Working Paper, No. 2145

Tazul, I., (2007) Microcredit and Poverty Alleviation. Ashgate Publishing Limited, England.

World Bank, (1990) World Development Report on Poverty. Oxford University Press, New York.

World Bank (1996) Nigeria: Poverty in the Midst of Plenty - the Challenge of Growth with Inclusion, Washington D.C.

World Bank Report, (2000) Entering the 21 ${ }^{\text {st }}$ Century. Oxford UniversityPress, New York.

World Bank Report, (2001) Attacking Poverty. Oxford University Press, New York.

World Bank, (2002) World Development Report. Washington D. C. 